\title{
Sexual Violence against Women, the Laws, the Punishment, and Negotiating the Duplicity
}

\author{
Suvarna Cherukuri
}

check for updates

Citation: Cherukuri, Suvarna. 2021. Sexual Violence against Women, the Laws, the Punishment, and Negotiating the Duplicity. Laws 10: 27. https://doi.org/10.3390/ laws10020027

Received: 17 January 2021

Accepted: 6 April 2021

Published: 13 April 2021

Publisher's Note: MDPI stays neutral with regard to jurisdictional claims in published maps and institutional affiliations.

Copyright: (C) 2021 by the author. Licensee MDPI, Basel, Switzerland. This article is an open access article distributed under the terms and conditions of the Creative Commons Attribution (CC BY) license (https:/ / creativecommons.org/licenses/by/ $4.0 /)$.
Department of Sociology, Siena College, Loudonville, NY 12211, USA; scherukuri@siena.edu

\begin{abstract}
On 16 December 2012, India erupted in national outrage against the rape of a 23-yearold female student in New Delhi, christened "Nirbhaya" (fearless). In the aftermath, there was a convergence of multiple discourses that framed post-independent India's feminist consciousness. In 2020, four men convicted of Nirbhaya's rape and murder were executed. An eight-year old girl in Kashmir was brutally raped and murdered in January 2018. The trial court sentenced the main accused to life in prison. In December 2019, four men held in yet another horrific rape and death of a 27-year veterinarian in Hyderabad were killed by the police in what has been called an extrajudicial killing. More recently, in 2020, a 19-year old was raped and killed in rural Uttar Pradesh. The victims came from different social locations, castes, tribes, and religious communities. This paper presents a feminist critique of the legal discourse on rape and the death penalty. It looks at an ironical cooptation of the critique of sexual violence by a patriarchal discourse on social injury and collective conscience. The paper examines how fleeting rage against the culprits and the call for death penalty immunizes larger misogynist cultural assumptions. This myopic rage is oblivious to sexual violence in women's daily lives. Finally, the paper looks at why legal reforms triggered by brutal acts of sexual violence, receiving widespread media attention, fail to achieve systemic societal changes.
\end{abstract}

Keywords: sexual violence; rape laws; duplicity; death penalty

\section{Introduction}

The National Crime Records Bureau (NCRB), the nodal agency that collects, compiles, and disseminates crime data in India, shows a 5.6\% increase in reported rape cases between 1971 and 2013. The NCRB documented similar trends during 1995-2013, wherein the cases of cruelty by husbands and relatives and dowry deaths increased at the rate of $6.8 \%$ per year. Gupta (2014) argues that the rate of increase in violence against women between 1971-2011 is greater than the $2 \%$ rate of population growth in India during the same time period. "However, one cannot use this data to make inferences about change in incidence of violence against women. Actual incidence of violence against women could have gone down, increased or remained more or less the same in this period" (Gupta 2014, p. 6). The 2019 NCRB crime data indicates a 7.3\% increase in reported rape cases since 2018 (Puri 2020). The NCRB also reports an alarming spike in child rape cases (Chandra 2018; Singh 2018).

An understanding of sexual violence has to confront multiple duplicities: cultural, legal, and political. The first challenge, however, is to avoid a conceptual confusion between reporting and incidence. Reported cases of crime do not reflect the total incidence of crime. Gupta (2014) shows the mismatch between reporting and incidence of violence against women by comparing data from the NCRB and the National Family Health Survey (NFHS, a survey of sample households in India). Using crime data from the NCRB to estimate reporting and NFHS to estimate incidence, Gupta (2014) documents that less than 1\% incidents of sexual violence cases were reported to the police. 


\section{Feminist Articulations against Sexual Violence in India}

The disjuncture between sporadic public outrage against sexual violence, laws against sexual violence, and sexual violence itself is nothing short of a cultural maze. More often than not, public moral outrage and a call to reform laws only emerge after sexual assaults against women, especially those receiving widespread media attention. "Appalling," "shocking the conscience of the nation," are the two popular responses. While the popular discourse and public outrage against selective acts of brutality ignore routine violence against women, the courts invoke the rarest of the rare doctrine from a landmark 1980 Supreme Court case to hand out the death penalty. The societal outrage and the juridical outcomes after what seem like "rare" brutal acts of sexual violence are ultimately a rushed exercise failing to look at violence as a more deeply embedded phenomenon. Feminist researchers have long argued that sexual violence against women constitutes social and political disorder in India (Das 1996; Baxi 2009). Whether it is communal riots, civil unrest, women's bodies become sites of brutal contestation- primary stakeholders being the perpetrators, the police, the courts, the policymakers, and the media. Butalia (1993) and Menon and Bhasin (1993) argue that modern India has witnessed violence against women since India's Partition. "Women were abducted, raped and nationalistic slogans like Victory to India and Long Live Pakistan were said to have been painfully inscribed on the private parts of women" (cited in Das 1996, p. 2411). The failure of addressing the "violence of normal times, leaves us with a gaping hole" when nationally visible rape cases like Nirbhaya capture our imagination (Kannabiran 2005).

Feminist mobilization has revolved around women victims and survivors of sexual violence since the 1970s. The landmark cases of sexual violence against women in India since the 1970s are Mathura (1972), Shaunbag (1973), Rameeza Bee (1979), Maya Tyagi (1980), Suman Rani (1989), Bhanwari Devi (1992), Mattoo (1996), Keeling (2009), Soumya (2011), Jyoti Pandey/Nirbhaya (2012), Shakti Mills Case (2013), Jisha (2016), Jisha (2018), Hathras (2020). The list is far from exhaustive. A few receive public visibility, unraveling modern India's caste, class, and religious dynamics. Feminist solidarity against sexual violence found its earliest expression in the 1972 Mathura rape case. Mathura, a young tribal girl, was raped in a police station by two policemen.

Feminist legal scholars' skepticism of legal control over women's subjective experiences of violence (Kapur 2006; Agnes 1992; Agnes 2001; Agnes 2013; Kannabiran and Kannabiran 2002; Menon 2004) may be understood in the context of the Supreme Court of India judgments discussed in this paper. The law is seen as a discriminatory instrument (Haksar and Singh 1986), as patriarchal (Sachs and Wilson 1978; Gonsalves 1993), ignoring women's experiences of oppression (MacKinnon 1983; Smart 1989).

\section{Methodology}

The paper examines the shift in the legal discourse of rape and sexual assault since the 1970s by analyzing the three Criminal Law (Amendment) Acts: The Criminal Law (Second Amendment) Act of 1983, The Criminal Law (Amendment) Act 2013, and The Criminal Law (Amendment) Act 2018. The paper analyzes 30 Supreme court judgments since 1975 related to rape (Section 376) and Section 302 (murder) sentencing.

\section{Sexual Violence and the Law: Shifts in the Discourse}

Nowhere is the British colonial legacy more visible than the inheritance of the legal and judicial discourse and the 1860 Indian Penal Code (IPC). The IPC continues to be the bedrock of the crime, punishment, and sentencing policy in India. In section 375 of the 1860 IPC, the perpetrator being male and the victim being female, rape was "limited to penile 
vaginal penetration."1 The role of courtroom talk in delegitimizing women's experiences of violence (as shown below in the Mathura case) is a harsh reality. Feminist legal theory in India (Das 1996; Kapur 2013; Dutta and Sircar 2013) has argued that the understanding of rape and sexual violence should move beyond the narrow confines of controlling sexuality to women's bodily integrity.

Until the 1980s, there was no change or amendment to the 1860 rape law. Significant Amendments related to rape and sexual assault in post-independent India followed three prominent cases (the Mathura case, the Nirbhaya Case, and the Kathua case). These trigger cases overshadow the routine day-to-day experiences of sexual violence since only a few cases receive national attention leading to legislative reforms. The Criminal Law (Second Amendment) Act of 1983 followed the 1978 Tukaram $v$ State of Maharashtra, referred to as the Mathura rape case. The Criminal Law (Amendment) Act 2013 was passed in the aftermath of the 2012 "Nirbhaya" rape case in the nation's capital. The Criminal Law (Amendment) Act 2018 was passed after the Kathua rape case.

The 1978 verdict systematically delegitimized Mathura's struggle by invoking the language of sexual morality/immorality and chastity. In 2012, the national moral outrage against the 16 December 2012 rape of a 23-year old student in New Delhi led to the convergence of multiple discourses that framed post-independent India's feminist consciousness. The public outrage saw the cooptation of feminist concerns like women's bodily integrity by the right-wing groups' apprehensions on the West's damaging influence, media, sex, and Valentine's Day. "Flaunting sexuality" meant inviting rapes (Kapur 2013). Hang the rapists became a slogan. The Government appointed the Justice Verma Committee, which

\footnotetext{
1 The Indian Penal Code 1860.
}

"375. Rape.-A man is said to commit "rape" who, except in the case hereinafter excepted, has sexual intercourse with a woman under circumstances falling under any of the six following descriptions:-

First.-Against her will. Secondly.-Without her consent. Thirdly.-With her consent, when her consent has been obtained by putting her or any person in whom she is interested in fear of death or of hurt. Fourthly.-With her consent, when the man knows that he is not her husband, and that her consent is given because she believes that he is another man to whom she is or believes herself to be lawfully married. Fifthly.-With her consent, when, at the time of giving such consent, by reason of unsoundness of mind or intoxication or the administration by him personally or through another of any stupefying or unwholesome substance, she is unable to understand the nature and consequences of that to which she gives consent. Sixthly.-With or without her consent, when she is under sixteen years of age.

Explanation.-Penetration is sufficient to constitute the sexual intercourse necessary to the offence of rape. Exception.-Sexual intercourse by a man with his own wife, the wife not being under fifteen years of age, is not rape" (IPC 1860: 165).

"376. Punishment for rape. (1) Whoever, except in the cases provided for by sub-section (2), commits rape shall be punished with imprisonment of either description for a term which shall not be less than seven years but which may be for life or for a term which may extend to ten years and shall also be liable to fine unless the woman raped is his own wife and is not under twelve years of age, in which case, he shall be punished with imprisonment of either description for a term which may extend to two years or with fine or with both:

1. Ins. by Act 18 of 1924, s. 4 .

2. Subs. by Act 43 of 1983, s.3 for the heading "Of rape" and ss. 375 and 376.

Provided that the court may, for adequate and special reasons to be mentioned in the judgment, impose a sentence of imprisonment for a term of less than seven years.

(2) Whoever,

(a) being a police officer commits rape

(i) within the limits of the police station to which he is appointed; or

(ii) in the premises of any station house whether or not situated in the police station to which he is appointed; or

(iii) on a woman in his custody or in the custody of a police officer subordinate to him; or

(b) being a public servant, takes advantage of his official position and commits rape on a woman in his custody as such public servant or in the custody of a public servant subordinate to him; or

(c) being on the management or on the staff of a jail, remand home or other place of custody established by or under any law for the time being in force or of a women's or children's institution takes advantage of his official position and commits rape on any inmate of such jail, remand home, place or institution; or

(d) being on the management or on the staff of a hospital, takes advantage of his official position and commits rape on a woman in that hospital; or

(e) commits rape on a woman knowing her to be pregnant; or

(f) commits rape on a woman when she is under twelve years of age; or

(g) commits gang rape,

shall be punished with rigorous imprisonment for a term which shall not be less than ten years but which may be for life and shall also be liable to fine:

Provided that the court may, for adequate and special reasons to be mentioned in the judgment, impose a sentence of imprisonment of either description for a term of less than ten years.

(IPC 1860: 166). 
invoked much-needed language on gender justice, sexuality, bodily integrity, and political empowerment (Verma 2013).

\subsection{The Criminal Law (Second Amendment) Act of 1983}

On 26 March 1972, an Adivasi (tribal) girl was raped by policemen in Maharashtra's police station. Released by the Sessions Court, convicted at the High Court, the Supreme Court of India, in a shocking verdict, sided with the Sessions Court, setting the accused free. Summarizing the Sessions Court verdict, the Supreme Court said:

"The Sessions Judge found that there was no satisfactory evidence to prove that Mathura was below 16 years of age on the date of occurrence. He held that Mathura was a shocking liar whose testimony is riddled with falsehood and improbabilities. The Court came to the conclusion that she had sexual intercourse while at the police station but rape had not been proved and that she was habituated to sexual intercourse..." (Tukaram v State of Maharashtra 1972).

The Supreme Court goes on to say:

"As pointed out earlier, no marks of injury were found on the person of the girl after the incident and their absence goes a long way to indicate that the alleged intercourse was a peaceful affair, and that the story of a stiff resistance having been put up by the girl is all false. It is further clear that the averments on the part of the girl that she had been shouting loudly for help are also a tissue of lies ..." (Tukaram $v$ State of Maharashtra 1972).

On 16 September 1979, four prominent law professors addressed the Supreme Court on women's human rights.

"Your Lordship, this is an extraordinary decision sacrificing human rights of women under the law and the Constitution ... Your Lordship, does the Indian Supreme Court expect a young girl 14-16 years old, when trapped by two policemen inside the police station, to successfully raise alarm for help? Does it seriously expect the girl, a laborer, to put up such stiff resistance against well-built policemen so as to have substantial marks of physical injury? Does the absence of such marks necessarily imply absence of stiff resistance? From the facts of the case, all that is established is submission, and not consent. Could not their Lordships have extended their analysis of 'consent' in a manner truly protective of the dignity and right of Mathura? One suspects that the Court gathered an impression from Mathura's liaison with her lover that she was a person of easy virtue. Is the taboo against pre-marital sex so strong as to provide a license to Indian police to rape young girls? Or to make them submit to their desires in police stations?... The Court gives no consideration whatsoever to the socio-economic status, the lack of knowledge of legal rights, the age of victim, lack of access to legal services, and the fear complex which haunts the poor and the exploited in Indian police stations. ... a case like this with its cold-blooded legalism snuffs out all aspirations for the protection of human rights of millions of Mathuras in the Indian countryside. Why so?"

The Court's sexist assumptions like "habituated to sexual intercourse," in the controversial verdict resulted in a national feminist mobilization, leading to the Criminal Law (Second Amendment) Act of 1983. Section 114A was added to the Indian Evidence Act of 1872, wherein if a woman says she did not consent, it means she did not consent.

By blaming and delegitimizing the struggle of Mathura, the Tukaram v State of Maharashtra 1972 verdict also engages in a casteist discourse of inviolability of tribal, Dalit, and other marginalized women. 


\subsection{Criminal Law Amendment, 2013}

After the 2012 heinous sexual attack and rape in New Delhi, the public outrage was unprecedented. It eventually led to the passing of the Criminal Law (Amendment) Act, 2013.

The Criminal Law (Amendment) Act, 2013 expanded the definition of rape beyond its original penal-vaginal penetration (nonconsensual) and called for stringent punishment (Mitra and Satish 2014, p. 52). The 2013 Amendment to the Criminal Law broadened the scope to include various crimes perpetrated against women, including stalking, intimidation, assault, acid attack, and disrobing. The new law also makes an affirmative statement that "absence of physical struggle does not mean consent" (Criminal Law Amendment 2013).

It made the sentencing policy more stringent. In addition to increasing the sentence for gang rape from 20 years to life imprisonment (as against ten years to life imprisonment), three years for stalking, ten years for acid attacks, the Criminal Law Amendment 2013 introduced the death penalty in rape and murder cases or when a victim/survivor is left in a vegetative state. ${ }^{2}$ Though in some areas, the Criminal Law Amendment (2013) provides "just thinking about gender," by overlooking marital rape, it also retains the colonial and patriarchal foundations of the IPC 1860 (Nundy 2013).

2 The Criminal Law Amendment (2013) The two major amendments in Section 375:-(i) Subs. by Act 43 of 1983, s. 3, for the heading "Of rape" and ss. 375 and 376 and (ii) Subs. by Act 13 of 2013, s. 9, for sections 375, 376, 376A, 376B, 376C and 376D (w.e.f. 03-02-2013.)

"375. Rape.-A man is said to commit "rape" if he-

(a) penetrates his penis, to any extent, into the vagina, mouth, urethra or anus of a woman or makes her to do so with him or any other person; or

(b) inserts, to any extent, any object or a part of the body, not being the penis, into the vagina, the urethra or anus of a woman or makes her to do so with him or any other person; or

(c) manipulates any part of the body of a woman so as to cause penetration into the vagina, urethra, anus or any part of body of such woman or makes her to do so with him or any other person; or

(d) applies his mouth to the vagina, anus, urethra of a woman or makes her to do so with him or any other person, under the circumstances falling under any of the following seven descriptions:-

First.-Against her will.

Secondly.-Without her consent. hurt.

Thirdly.-With her consent, when her consent has been obtained by putting her or any person in whom she is interested, in fear of death or of

Fourthly.-With her consent, when the man knows that he is not her husband and that her consent is given because she believes that he is another man to whom she is or believes herself to be lawfully married.

Fifthly. - With her consent when, at the time of giving such consent, by reason of unsoundness of mind or intoxication or the administration by him personally or through another of any stupefying or unwholesome substance, she is unable to understand the nature and consequences of that to which she gives consent.

Sixthly.-With or without her consent, when she is under eighteen years of age.

Seventhly.-When she is unable to communicate consent.

Explanation 1.-For the purposes of this section, "vagina" shall also include labia majora.

Explanation 2.-Consent means an unequivocal voluntary agreement when the woman by words, gestures or any form of verbal or non-verbal communication, communicates willingness to participate in the specific sexual act:

Provided that a woman who does not physically resist to the act of penetration shall not by the reason only of that fact, be regarded as consenting to the sexual activity.

Exception 1.-A medical procedure or intervention shall not constitute rape.

Exception 2.-Sexual intercourse or sexual acts by a man with his own wife, the wife not being under fifteen years of age, is not rape.

376. Punishment for rape.-(1) Whoever, except in the cases provided for in sub-section (2), commits rape, shall be punished with rigorous imprisonment of either description for a term which shall not be less than seven years, but which may extend to imprisonment for life, and shall also be liable to fine.

(2) Whoever,-

(a) being a police officer, commits rape-

(i) within the limits of the police station to which such police officer is appointed; or

(ii) in the premises of any station house; or

(iii) on a woman in such police officer's custody or in the custody of a police officer subordinate to such police officer; or

(b) being a public servant, commits rape on a woman in such public servant's custody or in the custody of a public servant subordinate to such public servant; or 


\subsection{The Criminal Law (Amendment) Act, 2018}

The 2018 gang rape and murder of an eight-year-old girl in Rasana village near Kathua in Jammu and Kashmir led to the passing of the The Criminal Law (Amendment) Act, 2018.

(c) being a member of the armed forces deployed in an area by the Central or a State Government commits rape in such area; or $(d)$ being on the management or on the staff of a jail, remand home or other place of custody established by or under any law for the time being in force or of a women's or children's institution, commits rape on any inmate of such jail, remand home, place or institution; or

(e) being on the management or on the staff of a hospital, commits rape on a woman in that hospital; or

(f) being a relative, guardian or teacher of, or a person in a position of trust or authority towards the woman, commits rape on such woman; or

(g) commits rape during communal or sectarian violence; or

(h) commits rape on a woman knowing her to be pregnant; or

(i) commits rape on a woman when she is under sixteen years of age; or

(j) commits rape, on a woman incapable of giving consent; or

(k) being in a position of control or dominance over a woman, commits rape on such woman; or $(l)$ commits rape on a woman suffering from mental or physical disability; or

$(m)$ while committing rape causes grievous bodily harm or maims or disfigures or endangers the life of a woman; or

(n) commits rape repeatedly on the same woman,

shall be punished with rigorous imprisonment for a term which shall not be less than ten years, but which may extend to imprisonment for life, which shall mean imprisonment for the remainder of that person's natural life, and shall also be liable to fine.

Explanation.-For the purposes of this sub-section,-

(a) "armed forces" means the naval, military and air forces and includes any member of the Armed Forces constituted under any law for the time being in force, including the paramilitary forces and any auxiliary forces that are under the control of the Central Government or the State Government;

(b) "hospital" means the precincts of the hospital and includes the precincts of any institution for the reception and treatment of persons during convalescence or of persons requiring medical attention or rehabilitation;

(c) "police officer" shall have the same meaning as assigned to the expression "police" under the Police Act, 1861 (5 of 1861);

(d) "women's or children's institution" means an institution, whether called an orphanage or a home for neglected women or children or a widow's home or an institution called by any other name, which is established and maintained for the reception and care of women or children.

376A. Punishment for causing death or resulting in persistent vegetative state of victim.-

Whoever, commits an offence punishable under sub-section (1) or sub-section (2) of section 376 and in the course of such commission inflicts an injury which causes the death of the woman or causes the woman to be in a persistent vegetative state, shall be punished with rigorous imprisonment for a term which shall not be less than twenty years, but which may extend to imprisonment for life, which shall mean imprisonment for the remainder of that person's natural life, or with death.

376B. Sexual intercourse by husband upon his wife during separation.-Whoever has sexual intercourse with his own wife, who is living separately, whether under a decree of separation or otherwise, without her consent, shall be punished with imprisonment of either description for a term which shall not be less than two years but which may extend to seven years, and shall also be liable to fine.

Explanation.-In this section, "sexual intercourse" shall mean any of the acts mentioned in clauses $(a)$ to $(d)$ of section 375 .

376C. Sexual intercourse by a person in authority.-Whoever, being-

(a) in a position of authority or in a fiduciary relationship; or

(b) a public servant; or

(c) superintendent or manager of a jail, remand home or other place of custody established by or under any law for the time being in force, or a women's or children's institution; or

$(d)$ on the management of a hospital or being on the staff of a hospital, abuses such position or fiduciary relationship to induce or seduce any woman either in his custody or under his charge or present in the premises to have sexual intercourse with him, such sexual intercourse not amounting to the offence of rape, shall be punished with rigorous imprisonment of either description for a term which shall not be less than five years, but which may extend to ten years, and shall also be liable to fine.

Explanation 1.-In this section, "sexual intercourse" shall mean any of the acts mentioned in clauses $(a)$ to $(d)$ of section 375 .

Explanation 2.-For the purposes of this section, Explanation 1 to section 375 shall also be applicable.

Explanation 3.-"Superintendent", in relation to a jail, remand home or other place of custody or a women's or children's institution, includes a person holding any other office in such jail, remand home, place or institution by virtue of which such person can exercise any authority or control over its inmates.

Explanation 4.-The expressions "hospital" and "women's or children's institution" shall respectively have the same meaning as in Explanation to sub-section (2) of section 376 .

376D. Gang rape.-Where a woman is raped by one or more persons constituting a group or acting in furtherance of a common intention, each of those persons shall be deemed to have committed the offence of rape and shall be punished with rigorous imprisonment for a term which shall not be less than twenty years, but which may extend to life which shall mean imprisonment for the remainder of that person's natural life, and with fine: Provided that such fine shall be just and reasonable to meet the medical expenses and rehabilitation of the victim:

Provided further that any fine imposed under this section shall be paid to the victim.

376E. Punishment for repeat offenders.-Whoever has been previously convicted of an offence punishable under section 376 or section $376 \mathrm{~A}$ or section 376D and is subsequently convicted of an offence punishable under any of the said sections shall be punished with imprisonment for life which shall mean imprisonment for the remainder of that person's natural life, or with death" (Criminal Law Amendment 2013). 
The Criminal Law (Amendment) Act, $2018^{3}$ made the minimum punishment for rape of a girl below age 12 to 20 years, with the maximum of life or death penalty.

The eight-year-old girl belonged to the Muslim Bakarwal livestock herding community. While providing the historical context to the case, Sharma (2020) says: "What emerges through an exercise that connects past to present, colony to nation, is how the pending fate of a Bakarwal girl was first inscribed in colonial ink for being a nomad, and later fulfilled in Independent India for being a Muslim. The manner in which the colonial programme of stigmatizing nomadic societies, particularly its women and children, is being adapted, intensified and given renewed direction through Hindu hyper-nationalism is thus underscored" (Sharma 2020, p. 40). The brutality inscribed on the child's body is a tragic reminder of "Nirbhaya." Such heinous acts of violence and the inscription of inhumanity on women's bodies, in their immediacy, render the explanatory power of most disciplinary frameworks useless. The rape of a Muslim girl in a Hindu temple by a Temple custodian and a special police officer garnered local political support, testing the secular fabric of the Indian state (Sharma 2020).

The three significant Amendments to the Criminal Law were passed after horrifying acts of rape and sexual assault. These reveal deeply embedded sexist assumptions in the society, de-legitimization of rape victims and survivors, the state's role, and the fragile secular fabric. A culture of misogyny, compulsive heteronormative discourse, caste hegemonies, religious intolerance all contribute to sexual violence against women, children, and religious minorities.

\section{Death Penalty for Rape and Murder}

Societal punishment is a reflection of society. Modern punishment actively engages with the idea of deterrence. While summarizing both theoretical and empirical takeaways from deterrence research, Nagin $(2013 a, 2013 b)$ argues that the certainty of punishment has a stronger deterrence effect than the punishment.

Legal scholars, political theorists, sociologists, philosophers, and theologians have long debated the role of punishment. The sociology of punishment scholars argues that punishment to reduce crime is a simplistic way of looking at the relationship between crime and punishment (Rusche and Kirchheimer 1939; Foucault 1977). Punishment may not be about the crime at all. Foucault (Foucault and Rabinow (1984) asks we get rid of the "illusion" that penalty exists to reduce crime.

Referring to Michel Foucault and Discipline and Punish (Foucault 1977) as his "productive interlocutors," socio-legal theorist David Garland summarizes his monumental work on conceptualizing punishment in different ways (Garland 2019): punishment as a

\footnotetext{
3 Criminal Law (Amendment) 2018: In section 376 of the Penal Code,-
}

(a) in sub-section (1), for the words "shall not be less than seven years, but which may extend to imprisonment for life, and shall also be liable to fine", the words "shall not be less than ten years, but which may extend to imprisonment for life, and shall also be liable to fine" shall be substituted; (b) in sub-section (2), clause (i) shall be omitted; (c) after sub-section (2), the following sub-section shall be inserted, namely:- " (3) Whoever, commits rape on a woman under sixteen years of age shall be punished with rigorous imprisonment for a term which shall not be less than twenty years, but which may extend to imprisonment for life, which shall mean imprisonment for the remainder of that person's natural life, and shall also be liable to fine: Provided that such fine shall be just and reasonable to meet the medical expenses and rehabilitation of the victim: Provided further that any fine imposed under this sub-section shall be paid to the victim.".

5. After section 376A of the Penal Code, the following section shall be inserted, namely:-" 376AB. Whoever, commits rape on a woman under twelve years of age shall be punished with rigorous imprisonment for a term which shall not be less than twenty years, but which may extend to imprisonment for life, which shall mean imprisonment for the remainder of that person's natural life, and with fine or with death: Provided that such fine shall be just and reasonable to meet the medical expenses and rehabilitation of the victim: Provided further that any fine imposed under this section shall be paid to the victim.".

6. After section 376D of the Penal Code, the following sections shall be inserted, namely:- "376DA. Where a woman under sixteen years of age is raped by one or more persons constituting a group or acting in furtherance of a common intention, each of those persons shall be deemed to have committed the offence of rape and shall be punished with imprisonment for life, which shall mean imprisonment for the remainder of that person's natural life, and with fine: Provided that such fine shall be just and reasonable to meet the medical expenses and rehabilitation of the victim: Provided further that any fine imposed under this section shall be paid to the victim.

$376 \mathrm{DB}$. Where a woman under twelve years of age is raped by one or more persons constituting a group or acting in furtherance of a common intention, each of those persons shall be deemed to have committed the offence of rape and shall be punished with imprisonment for life, which shall mean imprisonment for the remainder of that person's natural life, and with fine, or with death: Provided that such fine shall be just and reasonable to meet the medical expenses and rehabilitation of the victim: Provided further that any fine imposed under this section shall be paid to the victim." 
relationship (Garland 1981), punishment as an institution (Garland 1990), punishment as a moral-political problem (Duff and Garland 1993), punishment as an element crime-control field (Garland 1992), and punishment as a dimension of penalty (Garland 1983). Garland (2012) aptly remarks that "a sociological look at punishment uses the study of society to understand punishment, but it also uses punishment to understand society" (p. 16).

An increase in the incidence and reporting of sexual violence has renewed the call for the death penalty. India's official crime data show the number of reported rapes of children increased from 8541 in 2012 to 19,765 in 2016. Section 376 E of The Criminal Law (Amendment) 2013 introduced the death penalty for repeat offenders. The Criminal Law (Amendment) 2018 introduced the death penalty for child rapes. The courts in India, however, differ vastly in their use of the death penalty. The lower courts give out more death sentences (Surendranath 2020). Even while posing an abstract social conscience, the Supreme Court was careful to temper death penalty in Sections 376/302 until the 2017 verdict on the "Nirbhaya" case. For instance, Trials courts imposed 102 death sentences in 2019, but the Supreme Court overturned 27 out of 36 cases that it heard (Surendranath 2020).

The following analysis of Supreme Court judgments on rape and murder (Sections 376 and 302) reveals that social injury and collective conscience are critical factors in death penalty sentencing. These cases show the disparity and inconsistency in death penalty sentencing. Does the misplaced call for the death penalty remove the societal gaze from deeply embedded sexism in the society, thereby, emboldening men to commit such brutal acts of violence against women?

\subsection{Rarest of the Rare: Constitutionality of Death Penalty in India}

In Bacchan Singh v. State of Punjab, 1980, the Supreme Court's doctrine of "rarest of the rare" affirmed the constitutionality of the death penalty.

"It is, therefore, imperative to voice the concern that courts, aided by the broad illustrative guidelines indicated by us, will discharge the onerous function with evermore scrupulous care and humane concern, directed along the highroad of legislative policy outlined in Section 354(3), viz., that for persons convicted of murder, life imprisonment is the rule and death sentence an exception. A real and abiding concern for the dignity of human life postulates resistance to taking a life through law's instrumentality. That ought not to be done save in the rarest of rare cases when the alternative option is unquestionably foreclosed" (Bacchan Singh v. State of Punjab, 1980.)

The court emphasizes that aggravating and mitigating factors must be taken into consideration. However, while affirming the death penalty's constitutionality, the court also "dilutes the scope of its imposition" (Sinha 2012, p. 11). By establishing that life imprisonment is the rule and the death penalty an exception, the Supreme Court does put restrictions on death penalty sentencing but at the same time leaves space for subjective interpretation of the "rarest of the rare" act of crime.

\subsection{Inconsistency in the Application of the Rarest of the Rare Doctrine: Death Sentence}

There is overwhelming evidence that death penalty sentences are inconsistent. In Mohd. Abdul Mannan v. State of Bihar, 2011, the Supreme Court upheld the death sentence of a 43-year-old accused that brutally raped and murdered a minor girl. The Court said:

"The postmortem report shows various injuries on the face, nails and body of the child. These injuries show the gruesome manner in which she was subjected to rape. The victim of crime is an innocent child who did not provide even an excuse, much less a provocation for murder. Such cruelty towards a young child is appalling. We are of the opinion that Appellant is a menace to the society and shall continue to be so and he cannot be reformed. We have no manner of doubt that the case in hand falls in the category of the rarest of the rare cases and 
the trial court had correctly inflicted the death sentence which had rightly been confirmed by the High Court"

(Mohd. Abdul Mannan v. State of Bihar, 2011).

In the "Nirbhaya" case, Mukesh $\mathcal{E}$ Anr v. State For Nct Of Delhi $\mathcal{E}$ Ors on 5 May 2017, the Supreme Court of India said:

"The gruesome offences were committed with highest viciousness. Human lust was allowed to take such a demonic form. The accused may not be hardened criminals; but the cruel manner in which the gang-rape was committed in the moving bus; iron rods were inserted in the private parts of the victim; and the coldness with which both the victims were thrown naked in cold wintery night of December, shocks the collective conscience of the society. The present case clearly comes within the category of rarest of rare case where the question of any other punishment is unquestionably foreclosed. If at all there is a case warranting award of death sentence, it is the present case" (Mukesh \& Anr v. State For Nct Of Delhi $\mathcal{E}$ Ors on 5 May 2017).

In Amrit Singh v. State of Punjab, 2006 the Supreme Court commuted the death sentence given by lower courts to life imprisonment for the rape and murder of a minor girl. The court said:

"The deceased died a painful death which would appear from impression of teeth on her lips. She did not have even a developed body ... The manner in which the deceased was raped may be brutal but it could have been a momentary lapse on the part of Appellant, seeing a lonely girl at a secluded place. He had no pre-meditation for commission of the offence. The offence may look a heinous, but under no circumstances, it can be said to be a rarest of rare cases ... In a case of this nature where the brutality with which the offense was committed leading to the death of the prosecutrix, in our opinion, maximum sentence should be imposed. Appellant, thus deserves imposition of Rigorous Imprisonment for life" (Amrit Singh v. State of Punjab 2006).

In the State of Maharashtra v. Suresh on 10 December, 1999, the Supreme Court admitted a little child:

"was subjected to the beastly sexual ravishment. The Sessions Judge found that all those circumstances were established and they formed themselves into a completed chain unerringly pointing to the guilt of the respondent ... We, therefore, set aside the impugned judgment and restore the conviction passed by the trial court. Regarding sentence we would have concurred with the Sessions Court's view that the extreme penalty of death can be chosen for such a crime, but as the accused was once acquitted by the High Court we refrain from imposing that extreme penalty in spite of the fact that this case is perilously near the region of "rarest of the rare cases" envisaged by the Constitution Bench in Bachan Singh v. State of Punjab, 1980 (State of Maharashtra v. Suresh on 10 December 1999).

In Amit v. State of Uttar Pradesh, 2012 the Supreme Court overturned the trial court and high court verdict in the rape and murder of a three-year old, while commuting the death sentence to life in prison. The court said:

"In the present case also, we find that when the appellant committed the offence he was a young person aged about 28 years only. There is no evidence to show that he had committed the offences of kidnapping, rape or murder on any earlier occasion. There is nothing on evidence to suggest that he is likely to repeat similar crimes in future. On the other hand, given a chance he may reform over a period of years" (Amit v. State of Uttar Pradesh, 2012). 
In one of the most controversial cases of recent times, the Nariyo v. the State Of Gujarat on 20 April 2018, and an earlier judgment by the trial court in 2012, there were no death sentences. In a 1621-page judgment, The Gujarat High Court documents the brutality:

"Infants and children were thrown in the fire and roasted to death. Women, mostly young girls, were stripped naked, molested, raped and burnt alive. The final toll at and near the passage was fifty-eight. Thus, while the offence committed near the passage is culpable homicide amounting to murder punishable under section 302 of the Penal Code, the gravity thereof is of a much greater degree, considering the brutal, savage, inhuman, barbaric and depraved manner in which it was committed, warranting a more severe sentence" (p. 1518).

In June 2019, a special court in Pathankot sentenced three in the rape and murder of the eight-year-old girl to life in prison. The inconsistency within and across courts is well-established.

Several extra-judicial factors beyond the traditional mitigating factors contribute to inconsistencies in punishment, especially the death penalty: caste, class, gender, religious, tribal, and political identities and affiliations of the victims, survivors, perpetrators, and the various functionaries of the criminal justice system.

\subsection{Collective Conscience}

The construction of penalty in Supreme Court judgments related to rape and murder and the death penalty mainly revolves around the notion of the collective conscience and social injury (Muzafar 2020).

In Machhi Singh E Ors. v. State of Punjab, 1983 the Supreme court expanded the "rarest of rare" doctrine to include aggravating factors and the notion of "collective conscience" of a community. The court says that the "rarest of the rare" doctrine should be applied in a situation where the "collective conscience" of a community is shocked.

" ... But the community will not do so in every case. It may do so (in rarest of rare cases) when its collective conscience is so shocked that it will expect the holders of the judicial power to inflict death penalty irrespective of their personal opinion as regards desirability or otherwise of retaining death penalty ... " (Machhi Singh $\mathcal{E}$ Ors. v. State of Punjab, 1983).

In Mohd. Mannan v. the State of Bihar, 2011, the Supreme Court upheld the death sentence in the rape and murder of a 7-year old girl.

"The appellant had stooped so low as to unleash his monstrous self on the innocent, helpless and defenseless child. This act no doubt had invited extreme indignation of the community and shocked the collective conscience of the society" (Mohd. Mannan v. State of Bihar, 2011).

Along with “collective conscience," Mukesh $\mathcal{E}$ Anr v. State For Nct Of Delhi E Ors ("Nirbhaya" case) also addresses society's expectations of the courts in giving deterrent punishment, though research shows no evidence that the death penalty acts as general deterrence.

"Where a crime is committed with extreme brutality and the collective conscience of the society is shocked, courts must award death penalty, irrespective of their personal opinion as regards desirability of death penalty. By not imposing a death sentence in such cases, the courts may do injustice to the society at large. Society has a reasonable expectation is that deterrent punishment commensurate with the gravity of the offence be awarded. When the crime is brutal, shocking the collective conscience of the community, sympathy in any form would be misplaced and it would shake the confidence of public in the administration of criminal justice system" (Mukesh E Anr v. State For Nct Of Delhi E Ors).

The concept of "collective conscience" is at the core of Durkheimian social theory. According to Durkheim, "collective conscience" is: "The totality of beliefs and sentiments 
common to average citizens of the same society forms a determinate system which has its own life; one may call it the collective or common conscience ... It is, thus, an entirely different thing from particular consciences, although it can be realized only through them (Durkheim [1893] 1964, pp. 79, 80).

For Durkheim, criminal law reflects or is an embodiment (Garland 1991) of society's moral values. An act of crime violates these collective beliefs and sentiments and provokes collective outrage. Punishment is a moral affirmation of societal values. However, the collective in "collective conscience" may be a reflection of a dominant group's values or "vision of social order" (Garland 1991; Garland 2013). Collective conscience may be seen "...as the political achievement of the dominant cultural groups whose particular vision of social order has achieved a measure of hegemony, rather than a given set of values that are somehow consensually shared" (Garland 1991, p. 125).

\section{Conclusions}

Brutal violence against women is a stark and tragic reality. The death penalty for a few, with an overall low conviction rate in rape cases, is not justice. The 2018 conviction rate in rape cases saw a decline from the previous year (Economic Times 2020; Menon 2020).

Most nations are on an abolitionist path; the death penalty is inconsistent and does not deter crime; globally, there is disproportionate sentencing of racial-ethnic, religious minorities to death and India is not an exception (Surendranath 2015); there cannot be a fair application of the death penalty; the "rarest of the rare" doctrine is left to subjective interpretations.

The demand for the death penalty may satisfy public moral outrage. At the outset, anecdotes may show that execution provides a sense of closure for the victims' families. However, victim family research documents a complex relationship between execution and closure. Santhanan (2017) discusses how an execution does not end a surviving family's pain. Vollum and Longmire (2007) find that surviving families, who are co-victims of capital punishment cases, are often ambivalent on the death penalty. The death penalty might not always soothe the pain of family members.

From the society, whose collective conscience the brutal acts seem to offend, we take away accountability. The invoking of collective conscience masks crime and punishment problems - why the brutal rapes and sexual assaults on women and children; what is the "rarest of the rare" about rampant sexual violence; why the death penalty for some and not for others? The selective public and moral outrage and call for the death penalty are enablers for further violence because rape and sexual assault become crimes against society and its collective conscience. Not against women and their bodily integrity. The result is a duplicitous rhetorical obeisance to the heightened social outrage on the one hand and an implicit enabling of everyday violence against women on the other.

Funding: This research received no external funding.

Institutional Review Board Statement: Not applicable.

Informed Consent Statement: Not applicable.

Data Availability Statement: Not applicable.

Conflicts of Interest: The author declares no conflict of interest.

\section{References}

\section{Archival Sources}

Amit v. State of Uttar Pradesh. 2012. 4 SCC 107 [Supreme Court of India]. Amrit Singh v. State of Punjab. 2006. (12) SCC 79 [Supreme Court of India].

Bachan Singh v. State of Punjab, AIR 1980Bachan Singh v. State of Punjab, AIR 1980 SC 898 [Supreme Court of India].

Criminal Law (Amendment) Act 1983.

Criminal Law (Amendment) Act 2013.

Criminal Law (Amendment) Act 2018. 
Mohd. Mannan v. State of Bihar. 2011. 5 SCC 317 [Supreme Court of India].

Mukesh \& Anr vs. State for Nct of Delhi \& Ors on 5 May, 2017Mukesh \& Anr vs. State for Nct of Delhi \& Ors on 5 May, 2017 [Supreme Court of India].

Machhi Singh \& Ors. v. State of Punjab, 1983Machhi Singh \& Ors. v. State of Punjab, 1983 [Supreme Court of India]

Nair, Shalini. Why death penalty for child rape, or why not. The Indian Express April 30, 2018Nair, Shalini. Why death penalty for child rape, or why not. The Indian Express April 30, 2018. Nariyo vs. State of Gujarat on 20 April, 2018.

Rajendra Prahladrao Wasnik v. State of Maharashtra. 2012. 4 SCC 37 [Supreme Court of India].

Singh, C. S. P. The Laws on Rape and Sexual Crimes.

State of Maharashtra vs. Suresh on 10 December, 1999State of Maharashtra vs. Suresh on 10 December, 1999 [Supreme Court of India]. Tukaram v State of Maharashtra. 1972. [Supreme Court of India].

\section{Published Sources}

Agnes, Flavia. 1992. Protecting Women against Violence? Review of a Decade of Legislation, 1980-89. Economic and Political Weekly 27: WS19-WS33. Available online: http:/ / www.jstor.org/stable/4397795 (accessed on 16 January 2021).

Agnes, Flavia. 2001. Law and Gender Inequality. New Delhi: Oxford University Press.

Agnes, Flavia. 2013. No Shortcuts on Rape: Make the Legal System Work. Economic and Political Weekly 48: 12-15. Available online: http:/ / www.jstor.org/stable/23391173 (accessed on 26 January 2021).

Baxi, Pratiksha. 2009. Violence of Political Rhetoric on Rape. Economic and Political Weekly 44: 15-16. Available online: http: / / www.jstor.org.ezproxy.siena.edu:2048/stable/25663413 (accessed on 6 January 2021).

Butalia, Urvashi. 1993. Community, State, and Gender: On Women's Agency during Partition. Economic and Political Weekly 17: WS12-WS24.

Chandra, Rakesh. 2018. The Heinous Crime of Child Rape: Whether Death Penalty is the Answer? International Journal of Legal Developments and Allied Issues 4: 425-36.

Das, Veena. 1996. Sexual Violence, Discursive Formations and the State. Economic and Political Weekly 31: 2411-23. Available online: http:/ / www.jstor.org/stable/4404561 (accessed on 29 January 2021).

Duff, Antony, and David Garland. 1993. A Reader on Punishment. New York: Oxford University Press.

Durkheim, Emile. 1964. The Division of Labor in Society, 1896-1897. New York: The Free Press. First published 1893.

Dutta, Debolina, and Oishik Sircar. 2013. India's Winter of Discontent: Some feminist Dilemmas in the Wake of a Rape. Feminist Studies 39: 293-306.

Economic Times. 2020. Conviction Rate for Rape only 27.2\% Even as Country Celebrates Justice in Nirbhaya Case. Available online: https: / / economictimes.indiatimes.com/news/politics-and-nation/conviction-rate-for-rape-only-27-2-even-as-countrycelebrates-justice-in-nirbhaya-case/articleshow /73169787.cms?from=mdr (accessed on 6 January 2021).

Foucault, Michel. 1977. Discipline and Punish. New York: Pantheon.

Foucault, Michel, and Paul Rabinow. 1984. The Foucault Reader. New York: Pantheon.

Garland, David. 1981. The Birth of the Welfare Sanction. British Journal of Law and Society 8: 29. [CrossRef]

Garland, David. 1983. Philosophical Argument and Ideological Effect. Contemporary Crises 7: 79-85. [CrossRef]

Garland, David. 1990. Punishment and Modern Society: A Study in Social Theory. Chicago: University of Chicago Press.

Garland, David. 1991. Sociological perspectives on punishment. Crime and Justice 14: 115-65. [CrossRef]

Garland, David. 1992. Criminological Knowledge and its Relation to Power. British Journal of Criminology 32: 403. [CrossRef]

Garland, David. 2012. Peculiar Institution: America's Death Penalty in an age of Abolition. Cambridge: Harvard University Press.

Garland, David. 2013. Punishment and Social Solidarity. In The SAGE Handbook of Punishment and Society. Edited by Simon Jonathan and Richard Sparks. London: Sage.

Garland, David. 2019. Reading Foucault: An Ongoing Engagement. Journal of Law and Society, 640-661. [CrossRef]

Gonsalves, Lina. 1993. Women and the Law. New Delhi: Lancer Paperbacks.

Gupta, Aashish. 2014. Reporting and Incidence of Violence against Women in India; Working Paper. Research Institute for Compassionate Economics. Available online: http:/ / riceinstitute.org/wordpress/wp-content/uploads/downloads/2014/10/Reporting-andincidence-ofviolence-against-women-in-India-working-paper-final.pdf (accessed on 6 October 2017).

Haksar, Nandita, and Anju Singh. 1986. Demystification of Law for Women. New Delhi: Lancer Press.

Kannabiran, Kalpana. 2005. Violence of Normal Times. Delhi: Women Unlimited.

Kannabiran, Kalpana, and Vasantha Kannabiran. 2002. De-Eroticizing Assault: Essays on Modesty, Honour and Power. Calcutta: Stree.

Kapur, Ratna. 2006. Human rights in the 21st century: Take a walk on the dark side. Sydney Law Review $28: 665$.

Kapur, Ratna. 2013. Gender, Sovereignty and the Rise of a Sexual Security Regime in International Law and Postcolonial India. Melbourne Journal of International Law 14: 317.

MacKinnon, C. A. 1983. Feminism, Method and the State: An Agenda for Theory. Signs 7: 519-20.

Menon, Nivedita. 2004. Recovering Subversion: Feminist Politics beyond the Law. Champaign: University of Illinois Press.

Menon, M. 2020. A Deep Social Bias Marks the Judiciary's Response to Rape in India. In Economic E Political Weekly (Mumbai, India). NewsBank: Access World News. Available online: https:/ /infoweb.newsbank.com/apps/news/document-view?p=AWNB\& docref=news /1788DC7782CE98F0 (accessed on 3 January 2021). 
Menon, Ritu, and Kamala Bhasin. 1993. Recovery, Rupture, Resistance: Indian State and Abduct- ion of Women during Partition. Economic and Political Weekly 17: WS2-W12.

Mitra, Durba, and Mrinal Satish. 2014. Testing Chastity, Evidencing Rape: Impact of Medical Jurisprudence on Rape Adjudication in India. Economic and Political Weekly 49: 51-58. Available online: http:/ /www.jstor.org/stable/24480853 (accessed on 29 September 2020).

Muzafar, Aurif. 2020. Collective Conscience. In Economic \& Political Weekly (Mumbai, India). NewsBank: Access World News. Available online: https://infoweb.newsbank.com/apps/news/document-view?p=AWNB\&docref=news/17950E6292B805D0 (accessed on 3 January 2021).

Nagin, Daniel Steven. 2013a. Deterrence in the twenty-first century. Crime and Justice 42: 199-263. [CrossRef]

Nagin, Daniel Steven. 2013b. Deterrence: A review of the evidence by a criminologist for economists. Annual Review of Economics 5: 83-105. [CrossRef]

Nundy, Karuna. 2013. Explaining India's New Anti-Rape Laws. Available online: https://www.bbc.com/news/world-asia-india-21 950197 (accessed on 3 January 2021).

Puri, Nehal. 2020. Available online: https:/ / newsvibesofindia.com/violence-against-women-a-persistent-shadow-pandemic-44456/ (accessed on 3 January 2021).

Rusche, Georg, and Otto Kirchheimer. 1939. Punishment and Social Structure. Reprint. New York: Russell \& Russell.

Sachs, Albi, and Joan Hoff Wilson. 1978. Sexism and the Law. New York: Oxford.

Santhanan, Laura. 2017. Available online: https://www.pbs.org/newshour/nation/death-penalty-bring-closure-victims-family (accessed on 20 December 2020).

Sharma, Varun. 2020. Criminalizing Nomadic Femininity: Colonial Trail of the Kathua Rape-Murder. ANTYAJAA: Indian Journal of Women and Social Change 5: 40-51. [CrossRef]

Singh, Rohit. 2018. Depravity increasing? Spike in Child rapes. Hindustan Times, March 13.

Sinha, Satya Brata. 2012. To Kill or Not to Kill: The Unending Conundrum. National Law School of India Review 24: 1-29.

Smart, Carol. 1989. Feminism and the Power of Law. London: Routledge.

Surendranath, Anup. 2015. Death Penalty in India Is a Cruel Game of Chance. Available online: https://economictimes.indiatimes. com/opinion/interviews/death-penalty-in-india-is-a-cruel-game-of-chance-anup-surendranath/articleshow/48406397.cms? from $=$ mdr (accessed on 14 November 2020).

Surendranath, Anup. 2020. Abolition of the Death Penalty: A Tough Road ahead for India. In Economic E Political Weekly (Mumbai, India). NewsBank: Access World News. Available online: https://infoweb.newsbank.com/apps/news/document-view?p= AWNB\&docref=news /179AA536F5D00810 (accessed on 17 January 2021).

Verma, Jagdish Sharan. 2013. Report of the Committee on Amendments to Criminal Law, 2013. New Delhi: PRS Legislative Research.

Vollum, Scott, and Dennis Longmire. 2007. Covictims of capital murder: Statements of victims' family members and friends made at the time of execution. Violence and Victims 22: 601-19. [CrossRef] [PubMed] 